\title{
Motivasi Belajar: Dampak Komik Matematika Bernuansa Islami Berbantuan Instagram
}

\author{
Amiruddin $^{1 *}$, Nanang Supriadi ${ }^{2}$, Suherman ${ }^{3}$ \\ 1) 2) 3) Pendidikan Matematika, Fak. Tarbiyah dan Keguruan, Univeristas Islam Negeri Raden Intan Lampung \\ 1) amiruddinuddin98@gmail.com \\ ${ }^{2)}$ nanangsupriadi@radenintan.ac.id \\ 3) suherman@radenintan.ac.id \\ Open access article under the CC-BY-SA license
}

\begin{abstract}
ABSTRAK
Motivasi belajar dari peserta didik sangat berguna didalam proses pembelajaran. Salah satu pemanfaatan teknologi internet yaitu menggunakan media sosial sebagai media pembelajaran untuk menumbuhkan motivasi peserta didik. Penelitian ini bertujuan untuk menghasilkan produk berupa komik matematika yang layak, menarik dan dapat meningkatkan motivasi belajar peserta didik. Jenis penelitian yang digunakan dalam penelitian ini adalah research and development (R\&D) dengan model penelitian Borg dan Gall yang telah diperbarui oleh Sugiyono. Subjek penelitiannya adalah peserta didik kelas VII SMP Sentosa Bhakti Baturaja yang sedang menerima materi aritmatika sosial. Data dikumpulkan melalui angket, wawancara. Hasil penelitian menunjukkan bahwa produk komik matematika bernuasa islami berbantuan Instagram layak dan menarik serta dapat meningkatkan motivasi belajar peserta didik.
\end{abstract}

Kata Kunci: Motivasi Belajar, Komik, Islami, Instagram.

\begin{abstract}
Motivation to learn from students is very useful in the learning process. One of the uses of internet technology is using social media as a learning medium to foster student motivation. This study aims to produce a product in the form of mathematical comics that are feasible, interesting, and can increase students' learning motivation. The type of research used in this research is research and development (R\&D) with the Borg and Gall research model that has been updated by Sugiyono. The research subjects were seventh-grade students of junior high school Sentosa Bhakti Baturaja who were receiving social arithmetic material. Data were collected through questionnaires, interviews. The results showed that the Islamic mathematical comic products with the help of Instagram were feasible and interesting and could increase students' motivation to learn.
\end{abstract}

Keywords: Motivation Learn, Comic, Islamic, Instagram.

\section{A. PENDAHULUAN}

Motivasi belajar peserta didik sangatlah penting dalam proses pembelajaran dikarenakan motivasi belajar dapat mempengaruhi kebiasaan belajar, kegiatan dalam belajar, dan pengerjaan tugas di sekolah
(Budiarti \& Haryanto, 2016). Faktor yang dapat mempengaruhi prestasi siswa adalah motivasi, dengan adanya motivasi peserta didik akan belajar lebih tekun dan memiliki konsentrasi penuh dalam proses pembelajaran (Pratama et al., 2019). Hal tersebut didukung dengan 
pernyataan dari Emda (2018) bahwa ada tidaknya motivasi untuk belajar sangatlah dapat mempengaruhi keberhasilan belajar dari peserta didik. Keberhasilan dalam belajar dapat tercapai apabila didalam diri peserta didik adanya kemauan dan dorongan untuk belajar di dalam proses Pendidikan di sekolah.

Pendidikan dapat diartikan sebagai salah satu kegiatan yang dilakukan manusia terus menerus, dengan tujuan mengembangkan potensi dalam diri dan merubahnya ke arah yang lebih baik lagi (Setyawan \& Amir, 2020). Pendidikan juga salah satu proses interaksi antara pendidik dan peserta didik dalam hal mencapai tujuan yang telah di tentukan bersama-sama (Syazali, 2015). Dalam hal mencapai tujuan Pendidikan terdapat sarana dan prasarana, contohnya media pembelajaran yang digunakan pada saat proses pembelajaran agar mendapatkan hasil yang efektif dan efisien ditambahkan dengan manfaat internet dan media sosial (Irwandani \& Juariyah, 2016).

Dalam era teknologi internet pada saat ini pemanfaat kecanggihan internet untuk kepentingan pembelajaran sudah bukan hal yang baru lagi. Kemajuan ilmu pengetahuan dan teknologi menuntut seseorang untuk mempelajarinya, selain itu jaringan internet sudah banyak yang menggunakannya yang seharusnya dapat dimanfaatkan untuk menunjang kemajuan dalam Pendidikan (Arif Nugroho et al., 2017). Selain itu menambahkan teknologi informasi dalam proses pembelajaran dapat membuat peserta didik bereksplorasi pada materi yang disajikan, berlatih menggunakan pikiranya secara logis, analitis, sistematis, kritis dan kreatif serta dapat berkerjasama dalam menghadapai masalah (Supriadi, 2015). Hal itu didukung juga dengan pendapat Irwandani dan Juariyah (2016) bahwa pemanfaatan media sosisal sebagai media pembelajaran ialah salah satu manfaat dari adanya internet. Media pembelajaran merupakan alat yang digunakan untuk menyalurkan isi materi dari pendidik untuk peserta didik agar peserta didik dapat dengan mudah memahami materi yang disampaikan oleh pendidik (Asyhari \& Silvia, 2016).

Berdasarkan hasil dari observasi yang dilakukan oleh peneliti didapatkan bahwa media pembelajaran yang digunakan oleh pendidik dalam proses pembelajaran hanya menggunakan media pembelajaran seadanya, seperti busur, penggaris, jangkar, dan alat tulis lainnya. Hal tersebut perlu adanya pembaruan, dalam hal ini peneliti menggunakan media pembelajaran berupa komik matematika.

Komik matematika merupakan gabungan dari kata-kata dan gambar yang menjadi satu kesatuan, selain itu komik mempunyai tujuan yaitu menyebarkan informasi apapun kepada pembacanya (Soedarso, 2015). Komik juga dapat digunakan sebagai alat bantu mengajar untuk pendidik dan dapat digunakan oleh peserta didik untuk belajar sendiri (Saputro, 2015). Sesuai dengan pernyataan Widyawati dan Prodjosantoso (2015) bahwa komik merupakan 
potensial untuk meningkatkan motivasi belajar peserta didik.

Peneliti juga memberikan nilai-nilai islami didalam komik matematika tersebut. Penggunaan komik matematika yang bernuansa islami akan merangsang peserta didik untuk dapat mengaitkan materi matematika dengan kejadian atau peristiwa didalam kehidupan sehari-hari (Diana et al., 2018).

Berdasarkan hasil observasi $52 \%$ peserta didik menggunakan media sosial Instagram dan sisanya menggunakan twitter dan facebook. Berangkat dari hasil tersebut peneliti mencoba untuk mengembangkan media pembelajaran berbantuan instagram. Instagram merupakan aplikasi yang berfungsi untuk mengunggah, membuat filter, dan membagikan foto dan video ke semua media sosial yang ada (R. P. Utami et al., 2015).

Merujuk hasil penelitian terdahulu oleh Siregar dkk (2019) mengungkapkan bahwa komik yang dikembangkan layak dan dapat digunakan dalam proses pembelajaran. Selain itu penelitian oleh Prasetyono dkk (2015) bahwa adanya pengaruh yang signifikan terhadap penerapan media komik sebesar 0,61 dan dapat meningkatkan hasil belajar kognitif siswa. Relevansi antara penelitian terdahulu dengan penelitian yang dilakukan oleh peneliti yaitu menghasilkan produk komik. Sedangkan keterbaruan dari penelitian ini yaitu terdapat nuansa islami didalam komik dan penelitian ini berbantuan Instagram selain itu peneliti membahas tentang motivasi belajar peserta didik.

Berdasarkan hasil penelitian terdahulu maka penelitian ini bertujuan untuk menghasilkan komik matematika bernuansa islami berbantuan intagram yang layak, menarik dan dapat meningkatkan motivasi belajar peserta didik kelas VII SMP Sentosa Bhakti Baturaja.

Manfaat dari penelitian ini yaitu menumbuhkan motivasi belajar matematika peserta didik, dapat membantu pendidik menciptakan media pembelajaran yang lebih menarik, menambah pengetahuan bagi pendidik

\section{B. METODE}

Jenis penelitian yang digunakan pada pengembangan ini ialah Research and Development (R\&D) dengan menggunakan mode pengembangan Borg dan Gall yang telah diperbarui oleh Sugiyono. Adapun prosedur yang tersedia ada 10 tahap yang terdiri sebagai berikut (Sugiyono, 2018):

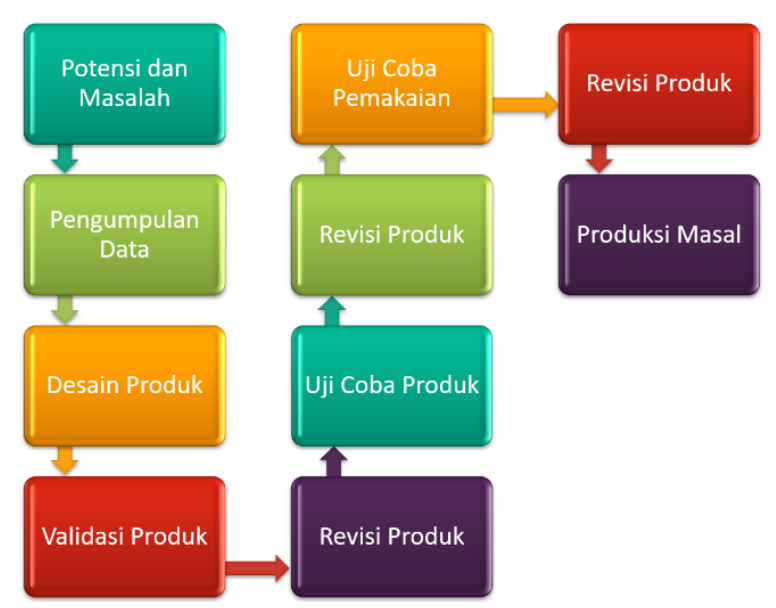

Gambar 1. Tahapan Model Borg dan Gall 
Instrumen yang digunakan adalah angket validasi ahli, respon peserta didik dan motivasi belajar peserta didik.

Dalam penelitian ini data akan dianalisa untuk mendapatkan media pembelajaran yang layak. Langkah-langkah yang akan dilakukan yaitu data berupa skor berskala 5 dari penilaian kelayakan produk oleh para ahli. Skor yang di peroleh akan dianalisa menggunakan rumus sebagai berikut:

$$
P=\frac{f}{N} \times 100 \%
$$

Keterangan:

$P=$ Angka persentase angket

$f=$ Jumlah skor yang diperoleh

$N=$ Jumlah skor maksimum

Selanjutnya hasil tersebut akan dikelompokkan berdasarkan kriteria interpretasi kelayakan menurut skala likert sebagai berikut:

Tabel 1. Skala Interpretasi Kelayakan

\begin{tabular}{ll}
\hline \multicolumn{1}{c}{ Penilaian } & \multicolumn{1}{c}{ Kriteria Interpretasi } \\
\hline $81 \% \leq \mathrm{P} \leq 100 \%$ & Sangat Layak \\
\hline $61 \% \leq \mathrm{P}<81 \%$ & Layak \\
\hline $41 \% \leq \mathrm{P}<61 \%$ & Cukup Layak \\
\hline $21 \% \leq \mathrm{P}<41 \%$ & Tidak Layak \\
\hline $0 \% \leq \mathrm{P}<21 \%$ & Sangat Tidak Layak \\
\hline
\end{tabular}

(T. N. Utami et al., 2018)

Analisa data uji coba produk atau angket respon peserta didik memiliki jawaban berupa skor berskala 5. Skor tersebut akan dianalisa menggunakan rumus sebagai berikut

$$
P=\frac{f}{N} x 100 \%
$$

Keterangan:

$P=$ Angka persentase angket

$f=$ Jumlah skor yang diperoleh

$N=$ Jumlah skor maksimum

Selanjutnya hasil tersebut akan dikelompokkan berdasarkan kriteria interpretasi kemenarikan sebagai berikut:

Tabel 2. Skala Interpretasi Kemenarikan

\begin{tabular}{ll}
\hline \multicolumn{1}{c}{ Penilaian } & \multicolumn{1}{c}{ Kriteria Interpretasi } \\
\hline $81 \% \leq P \leq 100 \%$ & Sangat Menarik \\
\hline $61 \% \leq P<81 \%$ & Menarik \\
\hline $41 \% \leq P<61 \%$ & Cukup Menarik \\
\hline $21 \% \leq P<41 \%$ & Tidak Menarik \\
\hline $0 \% \leq P<21 \%$ & Sangat Tidak Menarik \\
\hline
\end{tabular}

Analisa data untuk motivasi belajar untuk melihat peningkatan yang terjadi karena penggunaan media pembelajaran komik matematika. Langkah yang pertama menghitung gain ternomalisasi dengan rumus:

$$
N-\text { Gain }=\frac{\text { Skor Posttest }- \text { Skor Pretest }}{\text { Skor Maksimum }- \text { Skor Pretest }}
$$

Selanjutnya hasil terbut dapat ditentukan tinggi atau rendahnya berdasarkan tabel berikut:

Tabel 3. Kriteria Skor N-gain

\begin{tabular}{cc}
\hline Penilaian & Kategori \\
\hline $\mathrm{g}>0,7$ & Tinggi \\
\hline $0,3 \leq \mathrm{g} \leq 0,7$ & Sedang \\
\hline $\mathrm{g}<0,3$ & Rendah
\end{tabular}

(Wahyuni et al., 2020) 


\section{HASIL DAN PEMBAHASAN}

Hasil penelitian dimulai dengan tahap pertama yaitu mencari pontensi dan masalah. Pada sekolah tersebut memiliki potensi yang baik seperti peserta didik diperbolehkan untuk membawa handphone maupun smartphone dan ketersediaan media pembelajaran seperti busur, penggaris, jangkar, dan alat tulis lainnya, namun pendidik belum memanfaatkan perkembangan media pembelajaran. Hal itu didukung dari hasil observasi mengungkapkan bahwa media pembelajaran yang sedang digunakan kurang menarik yang berakibat peserta didik tidak memperhatikan pembelajaran. Setelah menetapkan potensi dan masalah, peneliti mengumpulkan data yang tediri dari buku-buku tentang materi arimatika sosial, buku-buku tentang komik dan silabus pembelajaran matematika kelas VII SMP. Selanjutnya adalah tahapan desain produk, yang berisi peneliti harus menentukan desain yang akan dibuat dalam media pembelajaran tersebut. Salah satu tampilan media bisa dilihat pada gambar-gambar berikut atau bisa dilihat di akun media sosial Instagram @komi_ka_ (www.instagram.com/komi_ka_)
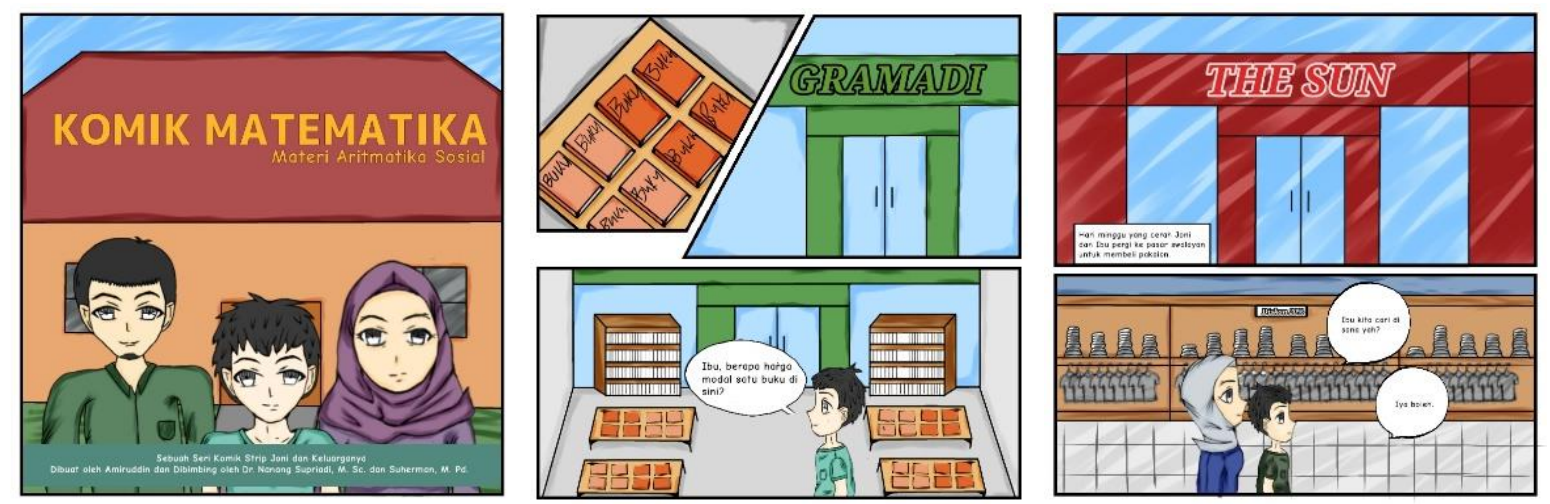

Gambar 2. Tampilan Komik Matematika

Tahapan selanjutnya ialah validasi desain kepada para ahli berguna untuk melihat kelayakan produk. Validasi desain akan dinilai oleh ahli materi, ahli media, dan ahli Bahasa. Berikut disajikan hasil penilaian validasi dari beberapa ahli.

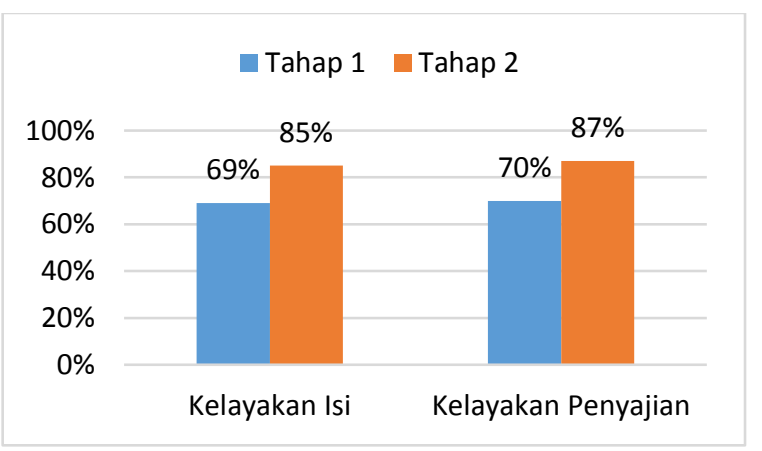

Gambar 3. Hasil Validasi Ahli Materi
Berdasarkan gambar 3 Hasil validasi ahli materi memperoleh dari aspek kelayakan isi tahap 1 mendapatkan persentase rata-rata 69\% dengan kriteria "Layak" dan pada tahap 2 didapatkan hasil persentase rata-rata $85 \%$ dengan kriteria "Sangat Layak". Sedangkan pada aspek kelayakan penyajian ditahap 1 mendapatkan persentase rata-rata $70 \%$ dengan kriteria "Layak" dan pada tahap 2 mendaptkan persentase rata-rata $87 \%$ dengan kriteria "Sangat Layak". 


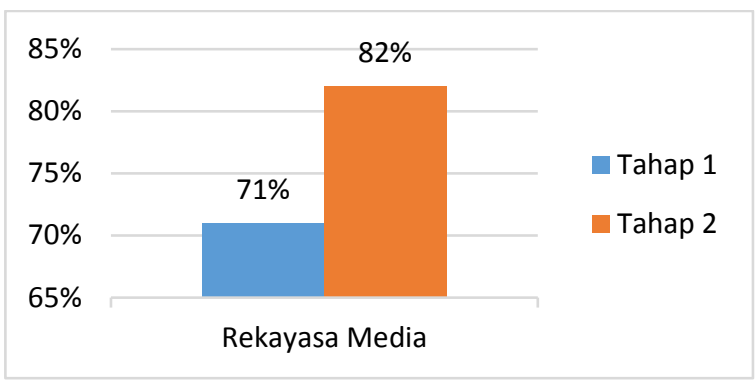

Gambar 4. Hasil Validasi Ahli Media

Berdasarkan gambar 4 Hasil validasi ahli media memperoleh dari aspek rekayasa media tahap 1 mendapatkan persentase rata-rata $71 \%$ dengan kriteria "Layak" dan pada tahap 2 didapatkan hasil persentase rata-rata $82 \%$ dengan kriteria "Sangat Layak".

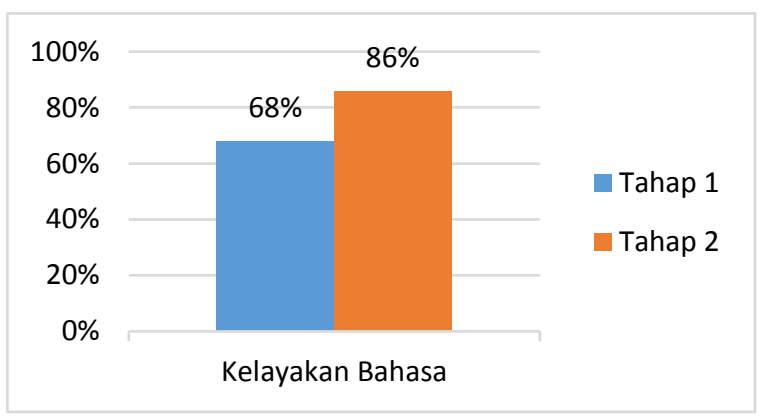

Gambar 5. Hasil Validasi Ahli Bahasa

Berdasarkan gambar 5 Hasil validasi ahli bahasa memperoleh dari kelayakan bahasa tahap 1 mendapatkan persentase rata-rata 68\% dengan kriteria "Layak" dan pada tahap 2 didapatkan hasil persentase rata-rata $86 \%$ dengan kriteria "Sangat Layak".

Setelah didapatkan hasil persentase rata-rata dari para ahli yang menyatakan produk "Sangat Layak", jadi produk sudah layak untuk digunakan pada proses uji coba produk. Tahap selanjutnya adalah uji coba produk. Pada uji coba produk dilakukan 2 kali tahap yaitu uji coba kelompok kecil dan uji coba lapangan. Berikut disajikan hasil uji coba produk.

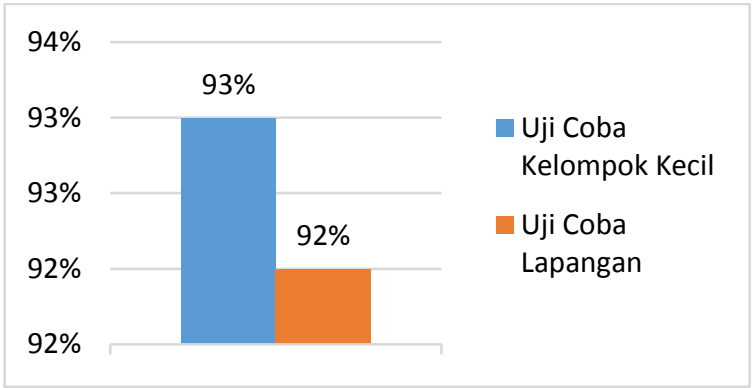

Gambar 6. Hasil Uji Coba Produk

Berdasarkan gambar 6 hasil uji coba produk didapatkan persentase rata-rata dari uji coba kelompok kecil 93\% dengan kriteria "Sangat Menarik" dan uji coba lapangan 92\% dengan kriteria "Sangat Menarik". Maka dengan hal ini dapat disimpulkan media yang dikembangkan sangat menarik untuk digunakan sebagai media pembelajaran.

Selanjutnya tahap uji coba pemakaian yang diberikan pada peserta didik kelas VII SMP Sentosa Bhakti Baturaja. Data yang diperoleh berupa hasil perhitungan angket motivasi belajar. Berikut disajikan hasil perhitungan angket motivasi belajar.

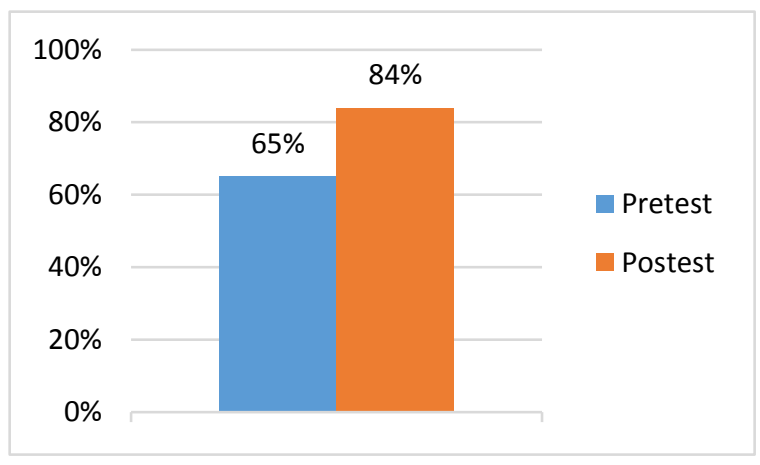

Gambar 7. Hasil Angket Motivasi Belajar

Berdasarkan gambar 7 hasil angket motivasi belajar pada uji coba pemakaian didapatkan persentase rata-rata dari pretest sebesar 65\%. Sedangkan persentase rata-rata dari postest sebesar $84 \%$. 
Data dari angket motivasi belajar dihitung menggunakan N-Gain dengan rata-rata skor tiap kategori disajikan pada tabel 4 .

Tabel 4. Rekapitulasi Nilai N-Gain

\begin{tabular}{cccc}
\hline $\begin{array}{c}\text { Nilai } \\
\text { Min. }\end{array}$ & $\begin{array}{c}\text { Nilai } \\
\text { Maks. }\end{array}$ & $\begin{array}{c}\text { Rata-rata } \\
\text { N-gain }\end{array}$ & kategori \\
\hline 0,07 & 0,81 & 0,51 & Sedang \\
\hline
\end{tabular}

Berdasarkan tabel 4 diatas diperoleh nilai minimum sebesar 0,07 dan nilai maksimum sebesar 0,81 dengan rata-rata N-Gain sebesar 0,51 dengan kategori sedang. Berdasarkan hasil tersebut dapat disimpulkan bahwa penggunaan komik matematika bernuansa islami berbantuan Instagram dapat meningkatkan motivasi belajar peserta didik dalam proses pembelajaran.

Setelah melalui beberapa tahap komik matematika bernuansa islami berbantuan Instagram siap untuk diunggah di akun media sosial instagram @komi_ka_ (www.instagram.com/komi_ka_).

\section{PENUTUP}

\section{Kesimpulan}

Berdasarkan hasil penelitian dan pengembangan dapat disimpulkan bahwa didapatkan suatu produk media pembelajaran komik matematika bernuansa islami berbantuan Instagram yang layak dan menarik untuk digunakan dalam pembelajaran. Selain itu komik matematika dapat meningkatkan motivasi belajar peserta didik.

\section{Saran}

Adapun saran yang perlu diperhatikan dalam pengembangan media pembelajaran adalah komik matematika bernuansa islami berbantuan Instagram ini perlu diperbaiki lagi dan disempurnakan Kembali seperti memperbaiki desain gambar dan menambahkan cerita yang lebih menarik sehingga membuat produk ini bermanfaat dan menghasilkan produk yang berkualitas. Selain itu media pembelajaran komik matematika bernuansa islami berbantuan Instagram perlu dikembangkan pada materi yang lain guna untuk membuat kegiatan pembelajaran dapat berlangsung efektif dan menarik.

\section{DAFTAR PUSTAKA}

Arif Nugroho, A., Wahyu Yunian Putra, R., Ganda Putra, F., \& Syazali, M. (2017). Pengembangan Blog Sebagai Media Pembelajaran Matematika. Al-Jabar: Jurnal Pendidikan Matematika, 8(2), 197-203.

Asyhari, A., \& Silvia, H. (2016). Pengembangan Media Pembelajaran Berupa Buletin dalam Bentuk Buku Saku untuk Pembelajran IPA Terpadu. Jurnal Ilmiah Pendidikan Fisika AlBiruni, 5(1), 1-13. https://doi.org/10.24042/jpifalbiruni.v5i1.100

Budiarti, W. N., \& Haryanto, H. (2016). Pengembangan Media Komik Untuk Meningkatkan Motivasi Belajar Dan Keterampilan Membaca Pemahaman Siswa Kelas Iv. Jurnal Prima Edukasia, 4(2), 233242. https://doi.org/10.21831/jpe.v4i2.6295

Diana, M., Netriwati, N., \& Suri, F. I. (2018). Modul Pembelajaran Matematika Bernuansa Islami dengan Pendekatan Inkuiri. Desimal: Jurnal Matematika, 1(1), 7-13. https://doi.org/10.24042/djm.v1i1.1906

Emda, A. (2018). Kedudukan Motivasi Belajar Siswa Dalam Pembelajaran. Lantanida Journal, 5(2), 172. https://doi.org/10.22373/lj.v5i2.2838 
Irwandani, I., \& Juariyah, S. (2016). Pengembangan Media Pembelajaran Berupa Komik Fisika Berbantuan Sosial Media Instagram sebagai Alternatif Pembelajaran. Jurnal IImiah Pendidikan Fisika Al-Biruni, 5(1), 33-42. https://doi.org/10.24042/jpifalbiruni.v5i1.103

Prasetyono, A. E., Amsia, T., \& Sri Ekwandari, Y. (2015). Pengaruh Penggunaan Media Komik Terhadap Peningkatan Hasil Belajar Sejarah. PESAGI : Jurnal Pendidikan dan Penelitian Sejarah, 3(6).

Pratama, F., Firman, F., \& Neviyarni, N. (2019). Pengaruh Motivasi Belajar Siswa Terhadap Hasil Belajar Ipa Di Sekolah Dasar. Edukatif : Jurnal IImu Pendidikan, 1(3), 280-286. https://doi.org/10.31004/edukatif.v1i3.63

Saputro, A. D. (2015). Aplikasi Komik sebagai Media Pembelajaran. Muaddib, 05(ISSN 2088-3390), 01.

Setyawan, D., \& Amir, A. (2020). Pengaruh Kemampuan Numerik terhadap Hasil Belajar Matematika pada Peserta Didik Kelas VII SMP Negeri 11 Maros Baru. Equals, 3(2), 85-94. https://doi.org/10.46918/equals.v3i2.757

Siregar, N., Suherman, S., Masykur, R., \& Ningtias, R. S. (2019). Pengembangan Media Pembelajaran E-Comic Dalam Pembelajaran Matematika. Journal of Mathematics Education and Science, 2(1), 11-19.

https://doi.org/10.32665/james.v2i1.47

Soedarso, N. (2015). Komik: Karya Sastra Bergambar. Humaniora, 6(9), 496-506.

Sugiyono, S. (2018). Metode Penelitian Pendidikan (Pendekatan Kuantitatif,
Kualitatif, dan R\&D) (27 ed.). ALFABETA.

Supriadi, N. (2015). Mengembangkan Kemampuan Koneksi Matematis Melalui Buku Ajar Elektronik Interaktif (BAEI) yang Terintegrasi Nilai-Nilai Keislaman. Al-Jabar: Jurnal Pendidikan Matematika, 6(1), 63-73.

Syazali, M. (2015). Pengaruh Model Pembelajaran Creative Problem Solving Berbantuan Maple II Terhadap Kemampuan Pemecahan Masalah Matematis. Al-Jabar: Jurnal Pendidikan Matematika, 6(1), 91-98.

Utami, R. P., Probosari, R. M., \& Fatmawati, U. (2015). Pengaruh Model Pembelajaran Project Based Learning Berbantu Instagram Terhadap Kemampuan Berpikir Kreatif Siswa Kelas X Sma Negeri 8 Surakarta. BioPedagogi, 4(1), 47-52.

Utami, T. N., Jatmiko, A., \& Suherman, S. (2018). Pengembangan Modul Matematika dengan Pendekatan Science, Technology, Engineering, And Mathematics (STEM) pada Materi Segiempat. Desimal: Jurnal Matematika, 1(2), 165. https://doi.org/10.24042/djm.v1i2.2388

Wahyuni, S., Yati, M., \& Fadila, A. (2020). Pengembangan Modul Matematika Berbasis REACT terhadap Kemampuan Komunikasi Matematis Peserta Didik. Jambura Journal of Mathematics Education, 1(1), 1-12. https://doi.org/10.34312/jmathedu.v1i1.4542

Widyawati, A., \& Prodjosantoso, A. K. (2015). Pengembangan Media Komik Ipa Untuk Meningkatkan Motivasi Belajar Dan Karakter Peserta Didik Smp. Jurnal Inovasi Pendidikan IPA, 1(1), 24-35. https://doi.org/10.21831/jipi.v1i1.4529 